\title{
SIMULATED COAL GAS MCFC POWER PLANT SYSTEM VERIFICATION
}

\author{
Technical Report
}

for

June 1998

For Work Performed Under DOE Contract No. DE-AC21-90MC27394

\author{
Presented to
}

Contractor Reports Receipt Coordinator

U.S. Department of Energy

Morgantown Energy Technology Center

3610 Collins Ferry Road

Morgantown, WV 26507

\section{Presented by}

J.A. Scroppo, Project Manager

M-C Power Corporation

8040 South Madison Street

Burr Ridge, IL 60521
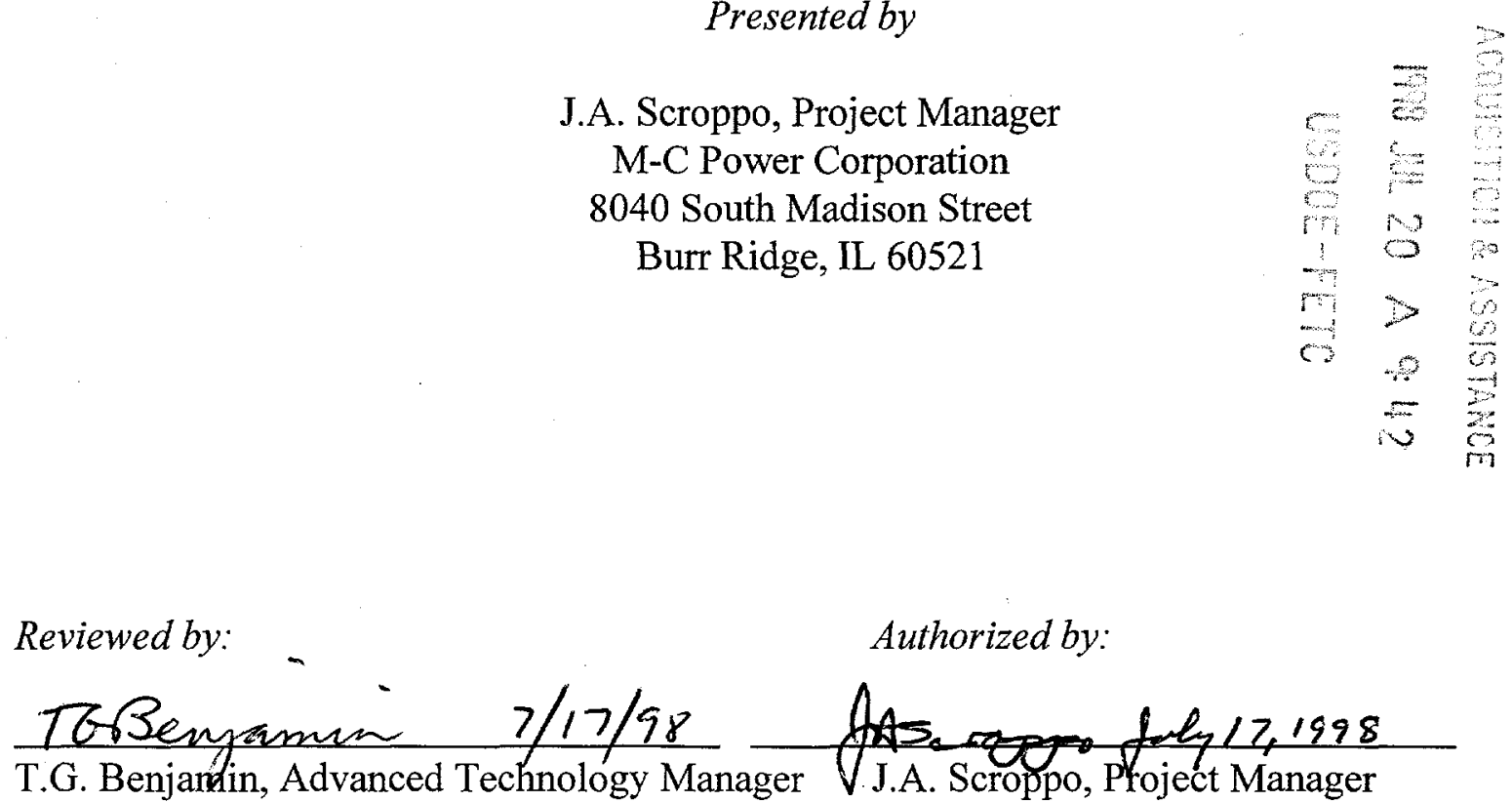


\section{DISCLAIMER}

This report was prepared as an account of work sponsored by an agency of the United States Government. Neither the United States Government nor any agency thereof, nor any of their employees, make any warranty, express or implied, or assumes any legal liability or responsibility for the accuracy, completeness, or usefulness of any information, apparatus, product, or process disclosed, or represents that its use would not infringe privately owned rights. Reference herein to any specific commercial product, process, or service by trade name, trademark, manufacturer, or otherwise does not necessarily constitute or imply its endorsement, recommendation, or favoring by the United States Government or any agency thereof. The views and opinions of authors expressed herein do not necessarily state or reflect those of the United States Government or any agency thereof. 


\section{DISCLAIMER}

Portions of this document may be illegible in electronic image products. Images are produced from the best available original document. 
MCP-009

June 1998

TABLE OF CONTENTS

Page

EXECUTIVE SUMMARY $\ldots \ldots \ldots \ldots \ldots \ldots \ldots \ldots \ldots \ldots \ldots \ldots \ldots \ldots \ldots \ldots \ldots$

TASK 2. POWER PLANT DEVELOPMENT $\ldots \ldots \ldots \ldots \ldots \ldots \ldots \ldots \ldots \ldots$

Subtask 2.6 Power Plant System Test with Reformed Natural Gas $\ldots \ldots \ldots \ldots$

TASK 4. TESTING FACILITY DEVELOPMENT $\ldots \ldots \ldots \ldots \ldots \ldots \ldots$

Subtask 4.2 Upgrading of Existing, U.S. Government-Owned, Test Facilities $\ldots .$.

TASK 6. ADVANCED RESEARCH AND TECHNOLOGY DEVELOPMENT . . . . . 1

Subtask 6.2 Advanced MCFC Component Research $\ldots \ldots \ldots \ldots \ldots \ldots \ldots \ldots$ 


\section{EXECUTIVE SUMMARY}

\section{Overview}

This is the Technical Progress Report covering June 1998. All tasks have been completed, except for those discussed on the following pages. Unocal estimated the costs of dismantling and packaging the test facility for storage and shipment. The scope of work for the contract has been modified to accommodate the dismantling and packaging of the plant. An amendment to Sub-Contract No. MCP-9-UNO between M-C Power and Unocal has been executed which includes the Scope of Work in Unocal's cost estimate.

\section{TASK 1. COMMERCIALIZATION}

This task is complete.

\section{TASK 2. POWER PLANT DEVELOPMENT}

A draft report of the stack performance and post-test analysis has been prepared and is undergoing internal review.

\section{TASK 3. MANUFACTURING FACILITIES DEVELOPMENT}

This task is complete.

\section{TASK 4. TESTING FACILITY DEVELOPMENT}

Unocal continued maintenance of the $250-\mathrm{kW}$ demonstration power plant and bid packages for plant dismantling have been prepared. The bid packages will be sent out by the end of the month.

\section{TASK 5. STACK RESEARCH}

This task is complete.

\section{TASK 6. ADVANCED RESEARCH AND TECHNOLOGY DEVELOPMENT}

The individual final reports from the Illinois Institute of Technology, Texas A\&M, and the University of Minnesota are being assembled into a complete final report. 


\section{Subtask 2.6 Power Plant System Test with Reformed Natural Gas Objective:}

To establish test goals, develop a power plant manual and operations plan, and conduct the $250-\mathrm{kW}$ power plant test.

\section{Discussion:}

A draft report on the $250-\mathrm{kW}$ stack performance and post-test analysis is undergoing internal review and editing for external distribution.

\section{Subtask 4.2 Upgrading of Existing, U.S. Government-Owned, Test Facilities Objective:}

To upgrade the existing, government-owned $20-\mathrm{kW}$ test facility to improve its reliability for long-term operation.

\section{Discussion:}

A work plan and estimate for dismantling and packaging the plant for shipment has been prepared by Unocal. The plan has been reviewed by M-C Power and Bechtel with modifications made where appropriate.

Unocal has obtained vendor qualifications for possible bidders who are acceptable to M-C Power. M-C Power is revising the bid packages to incorporate the modifications. Disassembly activities will proceed upon review of the proposals and subsequent releasing of a disassembly sub-contract. Shipment of the BOP from Unocal to M-C Power is expected to take place during December 1998.

\section{Subtask 6.2 Advanced MCFC Component Research Objective:}

To conduct research to resolve issues relating to the improvement of the efficiency and cost effectiveness of the MCFC by improving the following: protection of the current collector plate from corrosion; reduction of cathode over potential losses; understanding the effects of electrolyte basicity and oxygen reduction kinetics to reduce cathode over potential; and measuring the wetting angles of various electrolytes to reduce the electrolyte loss/migration during the MCFC operation.

\section{Discussion:}

Final reports have been received from IIT, UMinn, and Texas A\&M. They are being assembled into a report for submittal to FETC. 